\title{
Long-term randomized clinical trials of pharmacological treatment of obesity: Systematic review*
}

\author{
Lidia Castañeda-González, MD, MSc ${ }^{1}$, R afael Camberos-Solís, MD², \\ Montserrat Bacardi-G ascón, MD, E dD ${ }^{3}$, Arturo Jiménez-C
}

\section{SUMMARY}

Introduction: Obesity has become a public health problem. The increment in energy intake and the reduction of caloric expenditure as a result of sedentary lifestyles promotes a positive energetic balance resulting in the increase of fat deposits. In response to this, the prescription of pharmacological treatments has also increased.

Objective: To evaluate the long-term weight loss effectiveness of pharmacological treatments.

Methodology: A systematic review was conducted on randomized clinical trials registered in Pub Med, Scielo, and EBSCOHOST from January $1^{\text {st }} 1999$ to December $31^{\text {st }}$ 2008, including those with an intervention program with orlistat, sibutramine, and rimonabant equal or greater to two years. Two hundred and twelve articles were identified, 201 studies were excluded, and eleven were analyzed; seven from orlistat, two from sibutramine, and two from rimonabant. Information of design, intervention time, number of patients, age, body mass index and weight loss, difference between the intervention group versus the placebo, significance level, and methodological quality were obtained.

Main findings: The percentage of weight loss with orlistat ranged between 5 and $12 \%$, the mean weight loss was $8 \mathrm{~kg}$, and a difference between IG vs. placebo of $3.7 \mathrm{~kg}$. Weight loss with sibutramine ranged between 4 and $10 \%$, the mean weight loss was $7.4 \mathrm{~kg}$ and a difference between the intervention group versus placebo was $5.5 \mathrm{~kg}$. Weight loss with rimonabant was $7 \%$ with a mean weight loss of $7.3 \mathrm{~kg}$, and the difference compared with the placebo was $4.4 \mathrm{~kg}$.

Conclusions: Weight loss with pharmacotherapy is modest; weight regain after interruption of treatment, adverse effects, costs and lack of evidence related to long-term morbi-mortality, do not justify the generalized use of pharmacological treatment of obesity.

Keywords: Orlistat; Sibutramine; Rimonabant; Obesity; Pharmacotherapy.

Revisión sistemática de estudios clínicos aleatorios sobre el tratamiento farmacológico a largo plazo para la obesidad

\section{RESUMEN}

Introducción: La obesidad se ha convertido en un problema de salud pública. El incremento en el consumo energético y el menor gasto calórico, debido al sedentarismo, promueve un balance energético positivo que se traduce en el incremento de depósitos grasos. En respuesta al incremento de la obesidad se ha aumentado la prescripción del tratamiento farmacológico.

Objetivo: Evaluar la efectividad del tratamiento farmacológico sobre la pérdida de peso con un seguimiento igual o mayor a 2 años.

Metodologia: Se realizó una revisión sistemática de estudios aleatorios registrados en PubMed, Scielo y EBSCOHOST del 1 enero de 1999 al 31 de diciembre del 2008 y se seleccionaron aquellos con un período de intervención mayor o igual a dos años con orlistat (Or), sibutramina (Sib) y rimonabant (Ri). Se identificaron 212 artículos, se excluyeron 201 estudios y se analizaron once, siete de Or, dos de Sib y dos de Ri. Se obtuvo información del diseño del estudio, el tiempo de intervención,

* The study has been partially funded by CONACYT.

1. Medical and health sciences PhD student. Universidad Autónoma de Baja California, Facultad de Medicina y Psicología, Posgrado en Nutrición, Tijuana, México. e-mail: lidia_cst_md@yahoo.com.mx

2. Research assistant and general surgery resident, Universidad Autónoma de Baja California, Facultad de Medicina y Psicología, Posgrado en Nutrición, Tijuana, México. e-mail: rafaelcamberos@yahoo.com.mx m_bacardi@yahoo.com

3. Professor of the graduate Nutrition Program, Universidad Autónoma de Baja California, Facultad de Medicina y Psicología, Posgrado en Nutrición, Tijuana, México. e-mail: ajimenez@uabc.mx

Received for publication April 17, 2009 Accepted for publication January 12th, 2010 
el número de participantes, la edad, el índice de masa corporal (IMC), la pérdida de peso, la diferencia entre GI vs placebo, el nivel de significancia y la calidad metodológica.

Hallazgos: El porcentaje de pérdida de peso al final de la intervención con orlistat osciló entre 5\% y $12 \%$, un promedio de pérdida de $8 \mathrm{~kg}$ y una diferencia entre GI vs placebo de 3.7 $\mathrm{kg}$. Con sibutramina, entre $4 \%$ y $10 \%$, el promedio de pérdida de peso fue de $7.4 \mathrm{~kg}$ y diferencia entre GI vs placebo de $5.5 \mathrm{~kg}$. Con rimonabant, se observó en promedio $7.3 \mathrm{~kg}$ de pérdida de peso a los 2 años, y una diferencia con el grupo placebo de $4.4 \mathrm{~kg}$. El porcentaje de pérdida de peso fue de $7 \%$.

Conclusiones: La pérdida de peso con farmacoterapia es modesta, la recuperación posterior a la interrupción del tratamiento, los efectos adversos, el costo y la falta de evidencias sobre morbi-mortalidad a largo plazo, no justifican el tratamiento farmacológico generalizado de la obesidad.

Palabras clave: Orlistat; Sibutramine; Rimonabant; Obesidad; Farmacoterapia.

The rise in the prevalence of overweight and obesity in Latin American countries has been associated to rapid socioeconomic development, the adoption of hyperenergetic diets - high in fat content, sedentary lifestyles, and environmental changes during prenatal and postnatal development, and adulthood ${ }^{1}$. Increased energetic intake and lower caloric expenditure, due to a sedentary lifestyle, promote a positive energetic balance resulting in the augmentation of fat deposits ${ }^{2}$. The association of obesity with chronic diseases such as type-2 diabetes, osteoarthritis, and cardiovascular diseases results in greater costs in health services ${ }^{1,3}$.

Drug prescription for obesity has increased as a result of the elevated prevalence of obesity ${ }^{4}$. The latest approved drugs for obesity treatment may be classified into two categories:

1. Intestinal fat absorption inhibitors, such as Orlistat (Or) that inhibits pancreatic lipase and, consequently, about $30 \%$ of the fats ingested are not absorbed and are eliminated through the feces, generating an energetic deficit and thus weight loss.

2. Appetite suppressors, such as Sibutramine (Sib) that increase satiety or thermogenesis by means of sympathetic stimulation, generating elevated energetic waste and promoting weight loss ${ }^{5}$. Rimonabant (Ri), an antagonist of the canabinoid system CB1 receptors that promotes weight loss by suppressing appetite was also used in the market ${ }^{6}$.
Properly designed studies suggest that long-term effectiveness of weight reduction programs with drugs is associated to the inclusion of life-style changes. However, the main limitation of those studies has been the low retention rate of participants, low statistical significance, and the lack of intention to treat analysis. The objective of the current study is to evaluate the weight loss effectiveness of pharmacological treatments with Orlistat, Sibutramine, and Rimonabant in randomized control trials with a follow up equal to or greater than two years. An analysis of the cost of weight loss with pharmacological therapy at pharmacy prices in Mexico was included.

\section{METHODOLOGY}

The authors (LMCG and RCS) conducted a review of the articles registered in PUBMED, SCIELO, and EBSCOHOST published in English and Spanish with the following search data: «1999/01/01»: «2008/12/31» and «Obesity treatment» and «Randomized controlled trials» and «orlistat» or «sibutramine» or «rimonabant». To analyze the long-term effect on weight loss, the selected studies included a follow-up equal to or greater than 24 months. The design of the study, intervention period, number of participants, age, body mass index (BMI), amount of weight loss, difference between the intervention group (IG) vs. the placebo group, and significance level were analyzed in each article. The Jadad score was used to assess the quality of the studies. This score gives $0-2$ points when the study furnishes a description of randomization, 0-2 points to blinding, and 1 point when withdrawal subjects are mentioned in the study. The score ranges from 0 points for the lowest quality to 5 points for the highest quality ${ }^{7}$. Each article was independently analyzed by two researchers (LMC and RCS). The Kappa correlation coefficient between the two researchers was 0.93 . Disagreements or inconsistencies in the analysis were resolved by consensus. Afterwards, a final analysis was conducted by a third investigator (AJC), resolving the remaining disagreements. The Kappa correlation coefficient during this phase was 0.95 . The intervention cost of each drug was estimated from maximum market prices in Mexico during April 2008. The price of each drug treatment was calculated from the number of pills taken during the study period. 


\section{MAIN FINDINGS}

This review identified 212 potential articles related to the effectiveness of Orlistat $(\mathrm{Or})^{8-14}$, Sibutramine $(\mathrm{Sib})^{15,16}$, and Rimonabant (Ri) ${ }^{17,18}$ on weight loss. A total of 201 studies not meeting the inclusion criteria were eliminated and only 11 were analyzed, seven for Or, two for Sib, and two for Ri. Table 1 shows the characteristics and results of all the studies. The evaluation according to the Jadad score ranged from 2 to 5 points ${ }^{7}$. Most studies showed a significant difference among groups. As the control group was not included during the second year of intervention, it was not possible to evaluate the difference between the IG vs. placebo $^{13}$. Nine out of eleven studies reported intention to treat analysis $8,12,14,18$. Only the study where surgery was compared to medical treatment reported statistical significance $(>80 \%)^{13}$

\section{WEIGHT LOSS EFFECTS}

Orlistat. Davidson et al. ${ }^{8}$ included 1187 individuals in their initial single blind, 4-week initial phase with a hipocaloric diet. The placebo lead-in period was completed by 892 individuals, and these were randomized for a double-blind treatment for one year with a placebo or $120 \mathrm{mg}$ of Or. After drug assessments, those who showed treatment compliance with Or greater than $70 \%$ were randomized into three groups: 1) placebo, 2) $60 \mathrm{mg}$ of Or and $120 \mathrm{mg}$ of Or for a second year. Also, those in the placebo group that showed $70 \%$ compliance continued the same treatment for the following 52 weeks. All participants received periodic orientation on dietary intake, behavior modification on weight loss strategies, and seminars on weight maintenance. A total of $403(43 \%)$ subjects completed the two-year treatment. The Or group showed greater retention rates. The total weight loss at the end of the study was not specified. The study states that the proportion of weight loss was greater in the Or group and that weight gain at the end of the follow-up was greater in the placebo group.

Karhunen et al..$^{9}$ included 96 obese individuals in their two-year study. All were subjected to a four-week lead-in period that consisted of a hypo-caloric diet or placebo. Afterwards, they were randomly assigned for 52 weeks into two groups, either placebo t.i.d. or $120 \mathrm{mg}$ t.i.d. of Or in conjunction with a mildly hypo-energetic balanced diet. This period was followed by a doubleblind follow up for one year in combination with a weight maintenance diet. After four groups were formed, two groups received the same treatment for two years. The third group received Or during the first year and a placebo during the second year, and the fourth group received a placebo during the first year and Or during the second year. Throughout the study, all subjects were counseled by dietitians on the reduction of energy intake and who persuaded participants to perform physical activity. A hypo-energetic diet was prescribed with a 600-kcal/day deficit and adjusted every six months to reduce an additional 300-kcal/day without exceeding the total $1000-\mathrm{kcal} / \mathrm{day}$. The results revealed a weight loss of $12 \%$ in the Or group and $5 \%$ weight loss in the placebo group. After the two-year intervention period, a $7 \mathrm{~kg}(\mathrm{p}<0.001)$ difference between groups was observed. Although the study clearly indicated the total number of participants at the end of the study, the causes of withdrawal from the study by the individuals were not furnished. Nevertheless, the group initially under Or treatment that was later double-blinded to placebo regained $6 \mathrm{~kg}$ during the following twelve months.

Hauptman et al. ${ }^{10}$ evaluated the efficacy of Or in 796 adult individuals. Before the experimental study initiated, they were all subjected to a four-week singleblind placebo lead-in period combined with a hypoenergetic diet $(5,020-\mathrm{kJ} /$ day for those with weight $<90$ $\mathrm{kg}$ and $6,275-\mathrm{kJ} /$ day for those with weight $>90 \mathrm{~kg}$ ). A total of 635 individuals $(80 \%)$ concluded the initial phase of the study. Afterwards, all individual were randomly assigned into one of three groups: 1) placebo, 2) $60 \mathrm{mg}$, or 3) $120 \mathrm{mg}$ of Or during the following 52 weeks. During the second year, a weight maintenance diet was included with the same treatment to prevent weight regain. The caloric intake was increased in those individuals who continued losing weight after 52 weeks. Although the subjects only received nutritional guidance at the start of the placebo lead-in period by the study physician, dietitians were not involved in nutritional or behavioral counseling; they only recommended for participants to increase physical activity. The study revealed that during the first year the percentage of body weight was $4 \%$ for the placebo group and $8 \%$ for the $120 \mathrm{mg}$ t.i.d. Or group, with a difference between IG vs. placebo group of $4 \mathrm{~kg}(\mathrm{p}=0.001)$. At the end of the 
Table 1

Randomized controlled trials using Orlistat, Sibutramine, or Rimonabant

\begin{tabular}{|c|c|c|c|c|c|c|c|}
\hline Reference & Study design & $\mathbf{N}$ & $\begin{array}{c}\text { Age } \\
\text { (years) }\end{array}$ & $\begin{array}{c}\text { BMI } \\
\left(\mathrm{kg} / \mathrm{m}^{2}\right)\end{array}$ & Intervention & $\begin{array}{c}\mathrm{IT} \\
\text { (years) }\end{array}$ & $\begin{array}{c}\text { Retention } \\
\%\end{array}$ \\
\hline Davidson et al.19998 & $\begin{array}{l}\text { Parallel } \\
\text { Doubleblind }\end{array}$ & 1187 & $>18$ & $30-43$ & $\begin{array}{l}\text { Initial } 4 \text { weeks w/placebo } \\
+ \text { +HD } \\
\text { - Placebo + HD o Or } 120 \mathrm{mg} \\
\text { TID + HD (1 } 1 \text { st year) } \\
\text { - Placebo + HD } \\
\text { - Or } 60 \mathrm{mg} \text { TID + HD } \\
\text { - Or } 120 \mathrm{mg} \text { TID + HD }\end{array}$ & 2 & 34 \\
\hline Karhunen et al. $2000^{9}$ & Parallel $1^{\text {st }}$ year & 96 & $24-57$ & $29-44$ & $\begin{array}{l}4 \text { week initial phase with } \\
\text { placebo+HD } \\
\text {-PlaceboTID+DH } \\
\text { - Orlistat 120mg TID+DH }\end{array}$ & 2 & 75 \\
\hline Hauptman etal.2000 ${ }^{10}$ & $\begin{array}{l}\text { Parallel } \\
\text { Doubleblind }\end{array}$ & 796 & $>18$ & $30-44$ & $\begin{array}{l}4 \text { week initial phase } \\
\text { w/placebo + HD } \\
\text { - Placebo TID+HD } \\
\text { - Orlistat } 60 \mathrm{mg} \text { TID + HD } \\
\text { - Orlistat } 120 \mathrm{mg} \text { TID + HD }\end{array}$ & 2 & 52 \\
\hline Rossner et al.200011 & $\begin{array}{l}\text { Parallel } \\
\text { Doubleblind }\end{array}$ & 783 & $\geq 18$ & $28-43$ & $\begin{array}{l}4 \text { week initial phase } \\
\text { w/placebo + HD } \\
\text { - Placebo TID + HD } \\
\text { - } 60 \mathrm{mg} \text { Orlistat TID + HD } \\
\text { - 120mg Orlistat TID + DH }\end{array}$ & 2 & 60 \\
\hline Torgerson et al. $2004^{12}$ & $\begin{array}{l}\text { Parallel } \\
\text { Doubleblind }\end{array}$ & 3305 & $30-60$ & $\geq 30$ & $\begin{array}{l}\text { - Placebo TID + DH } \\
\text { - Orlistat 120mg TID + DH }\end{array}$ & 4 & 43 \\
\hline O'Brien et al.2006 & Parallel & 80 & $20-50$ & $30-35$ & $\begin{array}{l}\text { - Orlistat + VLCD } \\
\text { - Gastric band }\end{array}$ & 2 & 90 \\
\hline Richelsen et al. $2007^{14}$ & $\begin{array}{l}\text { Parallel } \\
\text { Doubleblind }\end{array}$ & 383 & $18-65$ & $30-45$ & $\begin{array}{l}\text { 8weeks with HD } \\
\text { - Placebo + HD } \\
\text { - Orlistat } 120 \mathrm{mg}+\text { HD }\end{array}$ & 3 & NA \\
\hline James et al. $2000^{15}$ & $\begin{array}{l}\text { Parallel } \\
\text { Doubleblind }\end{array}$ & 467 & $17-65$ & $30-45$ & $\begin{array}{l}6 \text { months with HD } \\
\text { - Placebo + nutritional } \\
\text { orientation } \\
\text { - Sibutramine } 10 \mathrm{mg} / \text { day + } \\
\text { nutritional orientation }\end{array}$ & 2 & 56 \\
\hline Redmon etal. $2005^{16}$ & Parallel $1^{\text {st }}$ year & 61 & $30-70$ & $27-50$ & $\begin{array}{l}\text { - CT group }{ }^{1} \text { (with sibu- } \\
\text { tramine): two years } \\
\text { - Control group: } 1 \text { year CEV } \\
\text { + HD; CT 2nd year }\end{array}$ & 2 & 79 \\
\hline Pi-Sunyer et al.2006 & Doubleblind & 3045 & $>18$ & $\begin{array}{l}>30 \text { or } \\
>27 \\
\text { w/disli- } \\
\text { pidemia }\end{array}$ & $\begin{array}{l}4 \text { initial phase with HD } \\
- \text { Placebo + PA + HD } \\
\text { Rimonabant + PA + HD } \\
5 \mathrm{mg} / \text { day } \\
\text { Rimonabant } 20 \mathrm{mg} / \text { day + } \\
\text { PA+HD }\end{array}$ & 2 & 37 \\
\hline Van Gaal et al.2008 ${ }^{18}$ & Doubleblind & 1507 & $>18$ & $\begin{array}{l}>30 \text { or } \\
>27 \\
\text { w/disli- } \\
\text { pidemia }\end{array}$ & $\begin{array}{l}4 \text { week with placebo and } \\
\text { HD } \\
- \text { Placebo + HD } \\
-5 \text { mg Rimonabant + HD } \\
-20 \text { mg Rimonabant + HD }\end{array}$ & 2 & 58 \\
\hline
\end{tabular}

IT: Intervention time; WP:Weight loss; PG: Placebo group;OG: Orlistat group; LSC: Life style changes; TID: Three times a day;

HD: Hipocaloric diet;NA: Not available, VLCD: Very low calorie diet; IG: Intervention group; DM2: Type 2 diabetes; BMI: Body mass index; ${ }^{1}$ CT: Combined therapy: CEV+HD: Meal replacement by supplements and sibutramine $10-15 \mathrm{mg} / \mathrm{day}$. 
Table 1

Randomized controlled trials using Orlistat, Sibutramine, or Rimonabant (continuation)

\begin{tabular}{|c|c|c|c|c|}
\hline Reference & $\begin{array}{l}\text { WL at end of } \\
\text { follow-up (kg) }\end{array}$ & $\begin{array}{l}\text { Difference placebo vs. } \\
\text { groups }(p)\end{array}$ & Comments & $\begin{array}{l}\text { Jadad's score } \\
\text { (R) points }\end{array}$ \\
\hline Davidson et al. $1999^{8}$ & $\begin{array}{l}\text { Or } 120=7.6 \% \\
\text { Or } 60 \mathrm{mg}=\mathrm{NA} \\
\text { Or+placebo=NA } \\
\text { Placebo }=4.5 \%\end{array}$ & NA & $\begin{array}{l}\text { Initial control energy diet ( } 30 \% \text { fat) } \\
75 \% \text { compliance was required for } \\
\text { randomization } \\
70 \% \text { compliance was required to } \\
\text { continue the } 2 \text { nd year }\end{array}$ & 3 \\
\hline Karhunen et al. $2000^{9}$ & $\begin{array}{l}-5.6 \\
-12.4\end{array}$ & $<0.001$ & $\begin{array}{l}600 \mathrm{kcal} / \text { day deficit diet A second } \\
\text { randomization took place during } \\
\text { the } 2 \text { nd year }\end{array}$ & 3 \\
\hline Hauptman etal.200010 & $\begin{array}{l}-1.7 \pm 0.6 \\
-4.5 \pm 0.6 \\
-5.0 \pm 0.7\end{array}$ & $\begin{array}{c}0.02 \\
0.002\end{array}$ & $\begin{array}{l}20 \% \text { withdrew before } \\
\text { randomization. } \\
\text { The caloric intake was established } \\
\text { according to body weight }>\text { or } \\
<90 \mathrm{~kg}\end{array}$ & 3 \\
\hline Rossner et al.2000"11 & $\begin{array}{l}4.3 \pm 7.5 \\
-6.8 \pm 8.4 \\
-7.6 \pm 7.0\end{array}$ & $\begin{array}{l}0.01 \\
0.001\end{array}$ & $\begin{array}{l}\mathrm{HD} \text { with } 600 \mathrm{Kcal} / \mathrm{day} \text { deficit }(30 \% \\
\text { fat). Treatment compliance of } 75 \% \\
\text { was required for randomized }\end{array}$ & 3 \\
\hline Torgerson et al. $2004^{12}$ & $\begin{array}{l}-3.0 \\
-5.8\end{array}$ & $<0.001$ & $800 \mathrm{kcal} /$ day diet deficit & 3 \\
\hline O'Brien et al. $2006^{13}$ & $\begin{array}{l}-5.3 \\
-20.5\end{array}$ & $<0.001$ & $\begin{array}{l}\text { Very low calorie diet, } 500-550 \mathrm{kcal} / \\
\text { day during } 12 \text { weeks }\end{array}$ & \\
\hline Richelsen et al. $2007^{14}$ & $\begin{array}{l}-6.3 c / P G \\
-8.3 c / O G\end{array}$ & $<0.028$ & $\begin{array}{l}\text { Very low calorie diet }(600- \\
800 \mathrm{kcal}) 19.3 \% \text { withdrew before } \\
\text { randomization }\end{array}$ & 4 \\
\hline James et al. $2000^{15}$ & $\begin{array}{l}-4.7 \\
-10.2\end{array}$ & $<0.001$ & $\begin{array}{l}\text { Most participants were white } \\
\text { women. Inclusion criteria: follow a } \\
600 \mathrm{Kcal} / \text { day diet and achieve } \geq \\
5 \% \text { weight loss }\end{array}$ & 5 \\
\hline Redmon etal. $2005^{16}$ & $\begin{array}{l}-4.6 \\
-8.1\end{array}$ & Does not apply & $\begin{array}{l}\text { DM2 patients } \\
\text { Basal BMI: } 38.5 \pm 1.1 \\
\text { No placebo group }\end{array}$ & 2 \\
\hline Pi-Sunyer et al.2006 ${ }^{17}$ & $\begin{array}{l}-2.5 \\
N A \\
7.5\end{array}$ & $\begin{aligned} & 0.02 \\
< & 0.001\end{aligned}$ & $\begin{array}{l}\text { Most participants were white } \\
\text { women who followed a } 600 \mathrm{Kcal} / \\
\text { day diet }\end{array}$ & 4 \\
\hline Van Gaal et al.2008 ${ }^{18}$ & $\begin{array}{l}-1.2 \\
-2.9 \\
-5.5\end{array}$ & $\begin{array}{l}0.007 \\
<0.001\end{array}$ & $\begin{array}{l}\text { Most individuals were white } \\
\text { females }\end{array}$ & 4 \\
\hline
\end{tabular}

IT: Intervention time; WP: Weight loss; PG: Placebo group;OG: Orlistat group; LSC: Life style changes; TID: Three times a day; HD: Hipocaloric diet; NA: Not available, VLCD: Very low calorie diet; IG: Intervention group; DM2: Type 2 diabetes; BMI: Body mass index; 1 CT: Combined therapy: CEV+HD: Meal replacement by supplements and sibutramine 10-15 mg/day.

second year, greater weight loss was observed in the $120 \mathrm{mg}$ Or group with 5\%, 4\% for the $60 \mathrm{mg}$ Or group, and $2 \%$ for the placebo group $(\mathrm{p}=0.001)$. The difference between groups was $3.3 \mathrm{Kg}$ (the placebo $v s .120 \mathrm{mg}$ Or) and $2.8 \mathrm{~kg}$ (placebovs. $60 \mathrm{mg}$ Or), both with a statistical significance of $\mathrm{p}=0.001$. However, the retention rate at the end of the study was $43 \%$ for the placebo group and $56 \%$ for the Or group.

Rossner et al. ${ }^{11}$ evaluated the effects of Or on weight loss and weight maintenance in 783 individuals. They initiated with a four-week lead-in period that included a balanced diet with a 600-kcal/day deficit. Individuals with $75 \%$ compliance to the diet were included for the following phase of the study. A total of 729 individuals were randomly assigned into three groups for the following 52 weeks: 1) placebo t.i.d., 2) $60 \mathrm{mg}$ Or t.i.d., or 3) $120 \mathrm{mg}$ Or in combination with the same hypo-energetic diet. They continued with the same diet during the second year and adjustments were made according to weight loss. At the end of the two years, the weight loss with the placebo was $4.5 \%$, with $60 \mathrm{mg}$ Or it was $6.8 \%(\mathrm{p}=0.012)$, and with $120 \mathrm{mg}$ Or 
it was $7.8 \%(\mathrm{p}<0.001)$. The difference between groups was $2.5 \mathrm{~kg}$ (placebo vs. $60 \mathrm{mg}$ Or) and $3.3 \mathrm{~kg}$ (placebo vs. $120 \mathrm{mg}$ Or). The retention rate at the end of the study was $60 \%$. A retention of $65 \%$ was observed in the 120 mg Or group.

Torgerson et al. ${ }^{12}$ in a four-year intervention study, evaluated the efficacy of Or on weight loss in 3,305 individuals. A $800 \mathrm{kcal}$ deficit diet was prescribed and adjusted every 6 months according to weight loss. During the first six months, nutritional counseling was provided every two weeks and every month thereafter, and individuals were encouraged to increase physical activity. At the end of the fourth-year follow-up, the difference between the IG vs. the placebo group was $2.8 \mathrm{~kg}(\mathrm{p}=0.001)$ and a total weight loss of $5.25 \%$ in the Or group and $2.7 \%$ in the placebo group. The retention rate at the end of the study was $52 \%$ for the Or group and $34 \%$ for the placebo group.

O'Brien etal. ${ }^{13}$ randomly assigned 40 adult individuals to lap gastric band and 40 individuals to a nonsurgical weight loss program that included an intensive 12 week program that included a $500-550 \mathrm{kcal} /$ day diet. Afterwards, they were subjected to a four-week transition program with a combination of a very low calorie diet and $120 \mathrm{mg}$ of Or t.i.d. The last phase of this same group consisted of a combination of a hypoenergetic diet and the same Or dosage. Considering a requirement of at least 72 subjects to fulfill a statistical significance of $80 \%, 80$ individuals were included in the study. A nutritional diet and increments of physical activity were encouraged for all participants. During the intensive phase, each individual was clinically evaluated every two weeks and every six weeks afterwards. Ninety-eight percent retention was observed in the surgical group and $83 \%$ in the Or group. The weight difference between groups was $15.2 \mathrm{~kg}$ with $\mathrm{p}<0.001$. The weight loss for the surgical group was $22 \%$ and $6 \%$ in the Or group.

Richelsen et al. ${ }^{14}$ conducted a study with 383 individuals and in the initial eight-week lead-in period a very low calorie diet(VLCD) was prescribed. A weekly follow up was carried out by a dietitian. A loss of at least $5 \%$ of initial weight was required for eligibility to the next phase. Eighty one percent (309) of the individuals were randomized to placebo or $120 \mathrm{mg}$ Or t.i.d. for the following three years in combination with a $600 \mathrm{kcal}$ restrictive caloric diet. During the first 18 months, all subjects were monitored every month and every three months thereafter. All were encouraged to increase physical activity. After the eight-week lead-in period with a very low balanced diet, the results of the study showed a weight loss of $14.3 \pm 2 \mathrm{~kg}$ in the Or group and of $14.5 \pm 2.1$ in the placebo group. The percentage of weight loss at the end of the study was $8.3 \%$ and $6.4 \%$ for the Or and placebo group, respectively $(\mathrm{p}<0.05)$. The difference between groups was $2 \mathrm{~kg}$. At the end of the study, the retention rate was $63 \%$ for the placebo group and $67 \%$ for the intervention group. Statistical significance and intention to treat analysis was not reported.

Sibutramine. James et al..$^{15}$ evaluated in a doubleblind study the efficacy of Sib on weight maintenance after a period of weight loss. During the first six months, 605 individuals initiated with a $600 \mathrm{kcal} /$ day diet deficit. Seventy seven percent (467) of the individuals that accomplished $\mathrm{a} \geq 5 \%$ weight loss were included in the following phase of the study. They were randomly assigned into two groups: 1) placebo and 2) those treated with Sib 10-20 mg/day. During the period of intervention, both groups received nutritional guidance every month. The results showed a $10 \%$ weight loss in the Sib group and a group difference of $5.5 \mathrm{~kg}$ compared to the placebo group $(\mathrm{p}<0.001)$. The retention rate was $49 \%$ in the placebo group and $57 \%$ in the Sib group. This study received the highest Jadad score (Table 1).

Redmon et al. ${ }^{16}$ conducted a study to evaluate the weight loss effect of Sib in 61 individuals with type-2 diabetes. One group received combined therapy (CT) that consisted of Sib, lifestyle changes, hypo-caloric diets, and meal replacement by supplements; another group received a standard therapy (ST) that consisted of lifestyle changes combined with a hypo-caloric diet during a one-year period. During the second year, the ST group was prescribed the CT and the initial CT group continued with the same treatment. At one year of intervention, a significantly greater loss of weight was observed in the CT group. At the end of the study, the average weight reduction in the CT group was $4 \%$. A significant weight loss between groups, $8 \mathrm{~kg}$ in the CT group ( $\mathrm{p}<0.001)$ and $5 \mathrm{~kg}$ in the $\mathrm{SR} / \mathrm{CT}$ group $(\mathrm{p}=0.001)$, was found. A total of 48 individuals ended the study, 23 in the CT group and 25 in the ST/CT. However, a $24-$ month follow up was not done with the ST group. In the CT group, weight regain was observed after ten months 
of intervention and more than half of the initial weight lost was regained at the end of the 24 months.

Rimonabant. Pi-Sunyeret al. ${ }^{17}$ conducted a doubleblind study and included 3,500 individuals of which 3,045 (87\%) met the four-week lead-in period with a $600 \mathrm{kcal} /$ day deficit diet. Theseindividuals were randomly assigned into three groups: 1) placebo, 2) 5-mg/day of Ri, and 3) 20-mg/day of Ri. A caloric-restricted diet and guidance on physical activity were included during the two-year follow up. The results showed a weight loss difference of $0.8 \mathrm{~kg}(\mathrm{p}=0.02)$ between the placebo and the $5 \mathrm{mg} /$ day $\mathrm{Ri}$ group, and a difference of $3.5 \mathrm{~kg}(\mathrm{p}<0.001)$ between the placebo and the $20 \mathrm{mg} /$ day $\mathrm{Ri}$ group. During the two-year follow up, $40 \%$ of the individuals treated with Ri achieved a $\geq 5 \%$ weight loss and $17 \%$ achieved a weight loss of $\geq 10 \%$. Furthermore, the placebo group showed that $19 \%$ lost $\geq 5 \%$ of the initial weight and $8 \%$ had a weight loss of $\geq 10 \%$ of the initial weight.

In a double-blind study conducted by Van Gaal et $a l .{ }^{18} 1507$ individuals were included in a four-week leadin period with a placebo and a hypo-caloric diet. Afterwards, all subjects were randomized into one of three groups: 1) placebo, 2) $5 \mathrm{mg} \mathrm{Ri}$, and 3) $20 \mathrm{mg} \mathrm{Ri}$ for the following two years. During the first month, all participants were scheduled for visits every 14 days and every 28 days thereafter. At the end of the two-year follow up, 886 individuals ended the study (58\%). The weight loss in the intention to treat was $1.2 \mathrm{~kg}$ in the placebo group, $2.9 \mathrm{~kg}$ in the $5 \mathrm{~m}$ Ri group, and $5.5 \mathrm{~kg}$ in the $20 \mathrm{mg}$ Ri group. Forty four percent of the individuals in the $20 \mathrm{mg}$ Ri group achieved a weight loss greater than $5 \%$ of the initial weight, compared to $30 \%$ of those treated with $5 \mathrm{mg} \mathrm{Ri}$ and $16 \%$ of those treated with a placebo. Eleven percent of the individuals treated with $20 \mathrm{mg}$ Ri achieved a weight loss $>10 \%$ of the initial weight compared to $22 \%$ of those treated with $5 \mathrm{mg} \mathrm{Ri}$ and $6 \%$ treated with a placebo.

Adverse efects. Gastrointestinal side effects have been described on $26 \%$ of the individuals who have used Or on weight reduction programs and the most common are: fecal urgency, increase on fecal depositions, fecal incontinency and flatulency, forcing many patients to suspend the treatment ${ }^{15}$. The most reported side effects with Sib use are infections (22\%), flu-like symptoms (14\%), headaches (14\%), appetite increase (14\%), pharingitis $(13 \%)$, dry mouth $(9 \%)$, constipation $(9 \%)$, hypertension (8\%), insomnia (8\%), abdominal pain (8\%), back ache $(8 \%)$, exanthema $(7 \%)$, asthenia $(7 \%)$, nausea $(7 \%)$, depression $(6 \%)$, and other less frequent symptoms ${ }^{16}$. Due to the side effects of Sib on blood pressure and cardiac frequency, constant medical evaluation is recommended.

The most common reported side effects with Ri use are upper airway infections (19\%), rhinopharingitis $(17 \%)$, nausea $(11 \%)$, arthralgias $(9 \%)$, flu infections $(9 \%)$, anxiety $(6 \%)$, back ache $(6 \%)$, insomnia $(6 \%)$, dizziness $(6 \%)$, viral gastroenteritis $(6 \%)$, depression $(5 \%)$, diarrhea (5\%), and other less frequent symptoms. Nevertheless, frequent psychological evaluations are recommended to avoid tragic effects. A high percentage of suicidal thoughts have been described in susceptible individuals ${ }^{18}$.

Costs. According to prices at drug stores in Mexico during 2008, the total expenses on a two-year treatment would be as follows: 1) \$4,500 dollars with $120 \mathrm{mg}$ Or three times a day, 2) $\$ 5,300$ dollars with Sib $20 \mathrm{mg} /$ day, and 3) $\$ 4,100$ dollars with Ri $20 \mathrm{mg} /$ day. With the minimum wage in Mexico, that cost would be equivalent to 850 to 1100 working days ${ }^{19}$. Evaluations and counseling by a physician, a nutritionist or a dietist, a psychologist, a physical activity trainer, lab and X-ray exams should also be added to the drug costs. In terms of the costs of each $\mathrm{kg}$ of weight lost, with the use of each drug it would be $\$ 750$ dollars for $\mathrm{Ri}, \$ 1,000$ dollars for Sib, and \$1,200 dollars for Or.

\section{DISCUSSION}

According to the criteria used on this systematic review, 11 randomized studies with a follow-up equal or greater than two years were found. Seven with $\mathrm{Or}^{8,14}$, two with $\mathrm{Sib}^{15,16}$, and two with $\mathrm{Ri}^{17,18}$. At the end of the intervention program with Or, the average weight loss was between 5 and $12 \%$ with Or and the longest followup study was conducted in four years; the percentage of weight loss observed was $5 \%{ }^{12}$. Between 4 and $10 \%$ of the initial weight was lost with the use of $\mathrm{Sib}^{15,16}$. These reported weight losses are similar to those observed in randomized controlled trials with a combination of diet and behavior-modification techniques ${ }^{20}$.

All studies showed a low-percentage retention rate and a significant group of individuals did not lose any weight. The moderate response to drugs is similar to 
other diet-only studies and behavior modification techniques; this might be due to genetic determined factors or to imprinting during the prenatal and the first years of life, to suppressed thermogenesis, or to an obesogenic environment. Although a modest weight reduction was observed, all studies showed a significant weight reduction compared to the placebo group.

Randomization was carried out after a caloric restriction period in 8 of the 11 studies. This indicates that the subjects included in each study were not representative of the general population. They were individuals able to follow a diet regime and their responses were ponderal to this restriction $8,11,14,15,17,18$. Only one study did not include a diet therapist to offer nutritional counseling, encourage physical activity, or prescribe restricted diets ${ }^{10}$. The statistical power was reported in only one study that compared medical treatment with surgical treatment ${ }^{13}$.

The results of this review are similar to those observed in numerous reviews and methanalysis by other authors, including interventions by means of behavior-modification techniques ${ }^{20}$. In general, short-term weight reduction is observed with medical treatment along with a tendency to regain the weight once the treatment is suspended. Nevertheless, there have been no reports on the followup time on which the weight lost is completely regained. This may be explained by the follow-up period, which has not been longer than four years and the low retention rate. In addition, the secondary effects have not been evaluated after four years with Or, two years with Sib, or two years with Ri. Most studieshave included obese, white women without cardiac, renal, liver, and gastrointestinal illnesses, as well as neuro-psychological diseases. On the Sib studies, hypertensive individuals were excluded, and on the Ri study individuals with neuro-psychiatric diseases were also excluded.

It is worth mentioning that a limitation to this review is the inclusion of studies conducted after 1999 and a follow-up greater than two years. In addition, the policies used by some researchers and editors may lead to a misleading conclusion, given that these individuals put aside publications where observed differences are not significant; also, there is no database that includes all randomized trials including those stopped due to high drop out rates or side effects.

In conclusion, the results of this review indicate that due to observed long-term weight loss, weight regain after pharmacological treatment, described side effects, costs, and lack of morbi-mortality evidence after four years, pharmacological treatment for obesity is not justified. Although it might be prescribed in specific cases where short-term weight reduction is mandatory due to medical reasons.

Conflict of interest. None of the authors has conflicts of interest related to this study.

\section{REFERENCES}

1. Jiménez-Cruz A, Bacardi-Gascón M. The fattening burden of type 2 diabetes on Mexicans. Diabetes Care. 2004; 27: 1213 5.

2. Flegal KM, Carroll MD, Ogden CL, Johnson CL. Prevalence and trends in obesity among US adults 1999-2000. JAMA. 2002; 288: 1723-7.

3. Ruiz AL, Castillo M, Orea A, Mejía S, Miguel A. Prevalence of self-reported overweight-obesity and its association with socioeconomic and health factors among older Mexican adults. Salud Pub Mex. 2007; 49: S482-7.

4. Hitchcock PN, Pugh JA. Management of overweight and obese adults. BMJ. 2002; 325: 757-61.

5. Glazer G. Long-term pharmacotherapy of obesity 2000: a review of efficacy and safety. Arch Intern Med. 2001; 161: 1814-24.

6. Van Gaal LF, Rissanen AM, Scheen AJ, Ziegler O, Rossner S. Effects of the cannabinoid-1 receptor blocker rimonabant on weight reduction and cardiovascular risk factors in overweight patients: 1year experience from the RIO-Europe study. Lancet. 2005; 365: 1389-97.

7. Jadad AR, Moore RA, Carroll D, Jenkinson C, Reynolds DJ, Gavaghan DJ, et al. Assessing the quality of reports of randomized clinical trials: is blinding necessary? Control Clin Trials. 1996; 17: 1-12.

8. Davidson MH, Haupman J, DiGirolamo, Foreyt JP, Halsted $\mathrm{CH}$, Heber $\mathrm{D}$, et al. Weight control and risk factor reduction in obese subjects treated for 2 years with orlistat: a randomized control trial. JAMA. 1999; 281:235-42.

9. Karhunen L, Franssila-Kallunki A, Rissanen P, Valve R, Kolehmainen M, Rissanen A, etal. Effect of orlistat treatment on body composition and resting energy expenditure during a two-year weight-reduction programme in obese Finns. Int $J$ Obes. 2000; 24: 1567-72.

10. Hauptman J, Lucas C, Boldrin MN, Collins H, Segal KR. Orlistat in the long-term treatment of obesity in the primary care settings. Arch Fam Med. 2000; 9: 160-7.

11. Rossner S, Sjostrom L, Noack R, Meiders E, Noseda G. Weight loss, weight maintenance, and improved cardiovascular risk factors after 2 years treatment with orlistat for obesity. Obes Res. 2000; 8: 49-61.

12. Torgerson JS, Hauptman J, Noack R, Boldrin MN, Sjostrom L. Xenical in the prevention of diabetes in obese subjects (xendos) study. Diabetes Care. 2004; 27: 155-61. 
13. O'Brien P, Dixon JB, Laurie C, Skinner S, Proletto J, Mcneil $\mathrm{J}$, et al. Treatment of mild to moderate obesity with laparoscopic adjustable gastric banding or an intensive medical program.Ann Inter Med. 2006; 144: 625-33.

14. Richelsen B, Tonstad S, Rossner S, Toubro S, Niskanen L, Madsbad S, et al. Effect of orlistat on weight regain and cardiovascular risk factors following a very-low-energy diet in abdominally obese patients. Diabetes Care. 2007; 30:27-32.

15. James WPT, Astrup A, Finer N, Hilsted J, Kopelman P, Rossner S, et al. Effect of sibutramine of weight maintenance after weight loss: a randomized trial.Lancet. 2000; 356:211925.

16. Redmon JB, Reck KP, Raatz SK, Swanson JE, Kwong CA, Ji $\mathrm{H}$, et al. Two-year outcome of a combination of weight loss therapies for type 2 diabetes. Diabetes Care. 2005; 28: 13115.
17. Pi-Sunyer FX, Aronne LJ, Heshmati HM, Devin J, Rosenstock J.Effect of rimonabant, a cannabinoid-1 receptor blocker, on weight and cardiometabolic risk factors in overweight or obese patients RIO-north America: a randomized controlled trial. JAMA. 2006; 295: 761-75.

18. Van Gaal LF, Scheen AJ, Rissanen AM, Rossner S, Hanotin C, Ziegler O. Long-term effect of $\mathrm{CB}^{1}$ blockade with rimonabant on cardiometabolic risk factors: two year results from the RIOEurope study. Eur Heart J.2008;29: 1761-71.

19. Diario oficial de la Federación. Secretaría de Gobernación, México 2008. Fecha de acceso 30 de abril, 2008. Disponible en: http//www.sat.gob.mx/sitio_internet/asistencia_contribuyente/informacion_frecuente/salarios_minimos

20. Márquez-IbañezB, Armendariz-Anguiano AL, Bacardí-Gascón M, Jiménez Cruz A. Revisión de ensayos clínicos controlados mediante cambios en el comportamiento para el tratamiento de la obesidad. NutrHosp. 2008; 28: 1-5. 